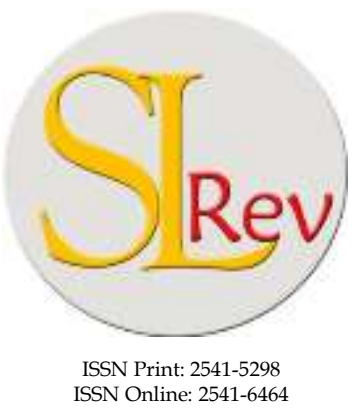

SRIWIJAYA

Editorial Office: Faculty of Law, Sriwijaya University

Jalan Srijaya Negara, Palembang, South Sumatra 30139, Indonesia

Phone: +62711-580063 Fax: +62711-581179

E-mail: sriwijayalawreview@unsri.ac.id | sriwijayalawreview@gmail.com

Website: http://journal.fh.unsri.ac.id/index.php/sriwijayalawreview

\title{
Abuse of Rights by Majority Shareholders in Indonesian Family-Owned Company: Is It Likely?
}

\author{
Fiona Priscilla Kohar ${ }^{\mathrm{a}}$ and Yetty Komalasari Dewi ${ }^{\mathrm{b}^{*}}$
}

a Faculty of Law, University of Oxford, England. E-mail: fiona.kohar@lmh.ox.ac.uk

$b^{*} \quad$ Faculty of Law, Universitas Indonesia, Indonesia. Corresponding Author: yetti.komalasari@ui.ac.id

\begin{tabular}{|c|c|}
\hline Article & Abstract \\
\hline $\begin{array}{l}\text { Keywords: } \\
\text { Abuse of Rights; Family- } \\
\text { owned Company; Legal } \\
\text { Protection; Majority } \\
\text { Shareholders. } \\
\text { Article History } \\
\text { Received: Oct 13, 2020; } \\
\text { Reviewed: Jan 7, 2021; } \\
\text { Accepted: Jan 24, 2021; } \\
\text { Published: Jan 31, 2021. }\end{array}$ & $\begin{array}{l}\text { The familial relations entwining the ownership and management of a family- } \\
\text { owned company creates a significant opportunity for majority shareholders } \\
\text { to exercise their rights to others' detriment. Various jurisdictions have } \\
\text { addressed such issue by projecting the concept of abuse of rights by majority } \\
\text { shareholders (abus de majorité). The concept aims to detect which behaviour } \\
\text { could be considered an abuse and provide legal protection for minority } \\
\text { shareholders and companies. In Indonesia, however, such a concept has not } \\
\text { been explicitly adopted nor discussed at length. This work examines what } \\
\text { behaviour which could be considered as a form of abuse of rights by } \\
\text { majority shareholders under the Indonesian company law, and how the } \\
\text { protection and practice of Indonesian private company law against such } \\
\text { behaviour. This work is a normative legal research using conceptual, } \\
\text { comparison, statutory, and case-law approaches. The comparison and case- } \\
\text { law approaches will be utilized to examine the universal concept of majority } \\
\text { shareholders abuse of rights by examining the adoption of the concept in } \\
\text { various jurisdictions and examine several relevant cases brought to the } \\
\text { Indonesian court. As a result, it concludes that there are still problems } \\
\text { surrounding the legal measures available, as this behaviour is still prevalent, } \\
\text { especially in Indonesia's family-owned companies. Hence, more stringent } \\
\text { rules are needed to protect minority shareholders and the Indonesian } \\
\text { Company's interests effectively. }\end{array}$ \\
\hline \multicolumn{2}{|c|}{$\begin{array}{l}\text { (O2021; This is an Open Access Research distributed under the term of the Creative Commons Attribution License } \\
\text { (https://Creativecommons.org/licences/by/4.0), which permits unrestricted use, distribution, and reproduction in } \\
\text { any medium, provided the original works is properly cited. }\end{array}$} \\
\hline
\end{tabular}

\section{INTRODUCTION}

In the era of technological advancement and innovations, businesses are expected to be well equipped to face any changes to maintain their prosperity. However, despite this common understanding, one issue remains unresolved. Most private companies owned by families (family-owned companies) still face a substantial internal problem in their decision-making process and their governance structures that are excessively centred on family. Disagreements in the decision-making process could lead to shareholder disputes. Such occurrence must not be 
taken lightly, since it is widely considered the primary cause of loss of management time and increased costs that would lead to a business failure, as Bahl noted in his article concerning disputes between shareholders. ${ }^{1}$

The most concerning matter that must be paid attention to when there is a shareholder dispute is the vulnerability of minority shareholders. It is because minority shareholders tend to come out as the victim of the majority's greed to further their interests, especially when the majority shareholders' family dominates the company's organs. The majority shareholders could easily use the General Meeting of Shareholders (GMS) to approve any matters proposed, albeit against Law No. 40 Year 2007 concerning Limited Liability Companies (Indonesian Company Law) or the Articles of Association (AoA). We also see this happens in other jurisdiction with a different legal system like the UK, as we can see through Krankmaan's exposition in his book. ${ }^{2}$ Furthermore, they could easily abuse their rights against the minority's interest by dismissing their GMS rights, removing them from managerial positions, halting them from receiving dividends and misusing the company's assets. ${ }^{3}$ This kind of behaviour is known as an abuse of rights by majority shareholders. ${ }^{4}$ The concept might lead to different terminologies in other jurisdictions. For example, in the UK, it is known as unfair prejudice. In individual states in the US, it is known as oppression, in Germany as mitgliedschaftliche treuepflicht. In the Netherlands, such behaviour can be understood as a violation of the principle of reasonableness and fairness. ${ }^{5}$ However, for this paper's purpose, the term abuse of rights by majority shareholders and abuse of rights will be used interchangeably.

There are several cases regarding disputes between shareholders in family-owned companies. These cases could give a clear depiction on how the Indonesian court treats disputes between shareholders.

To detect and prevent majority shareholders from abusing their rights, we need to identify first the forms of abuse of rights committed by majority shareholders in family-owned companies. Majority shareholders may abuse their rights by controlling the GMS to withhold dividends, dilute the minority's shares, or misuse the company's assets. They may also use their superior power to dominate the corporate boards.

If such conduct is committed, we would need to examine the forms of protection used by the Indonesian Company and the minority shareholders against such abuses. Minority shareholders may opt to take legal action against the majority's action. They can also invoke their right to demand their shares to be purchased at a fair price, purchase a newly issued share,

1 Steven C. Bahls, 'Resolving Shareholder Dissension: Selection of the Appropriate Equitable Remedy', Journal of Corporation Law, 15 (1990), 285-89.

2 Et.al Reineer Kraakman, The Anatomy of Corporate Law: A Comparative and Functional Approach (3) (Oxford: University Press, 2017).

3 Douglas K. Moll, 'Shareholder Oppression \& Dividend Policy in the Close Corporation', Washington \& Lee Law Review, 60.3 (2003), 841-924.

4 P. S.Sangal, 'Abuse of Authority by a Majority of Shareholders in a Company', Journal of the Indian Law Institute, 6.4 (1964), 380-409.

5 Holger Fleischer, 'Comparative Corporation Governance in Closely Held Corporations', in The Oxford Handbook of Corporate Law and Governance, ed. by J. N Gordon and W Ringeeds, The Oxford (Oxford: Oxford University Press, 2018). 
or conduct an inspection over the Indonesian Company. These forms of legal protection will be discussed at length in the Discussion and Analysis chapter.

The actual test, however, is to find out whether these legal measures are useful in practice. To assess this, we will go through several cases brought to the Indonesian court and examine whether these available measures are indeed effective.

\section{RESEARCH METHODS}

This work is normative legal research that uses four approaches: conceptual, comparison, statutory, and case-law. The conceptual approach will be utilized to examine the concept of the abuse of rights by majority shareholders. Simultaneously, the comparison approach will be utilized to examine the universal concept of majority shareholders abuse of rights by examining the adoption of the concept in various jurisdictions. The statutory approach will examine how the Indonesian Company Law protects against majority shareholders' abuse of rights. At the same time, the case-law approach will be applied by examining court decisions concerning disputes between majority and minority shareholders in family-owned companies.

The data used in this work comprise of secondary data collected from books and academic papers. The data is obtained through library research which covers desk review and online research. All data collected will be analyzed qualitatively in order to describe the forms of abuse of rights by majority shareholders and the legal measures available under the Indonesian Company Law to prevent such behaviour.

\section{ANALYSIS AND DISCUSSION}

Before excavating into the central point of this paper - i.e. the forms, the protection against and how sufficient is the protection against majority shareholders' abuse of rights - it is better to discuss the concept of abuse of rights by majority shareholders. The term is not yet explicitly recognized by the Indonesian Law and is known by different names in other jurisdictions.

The atomized shareholding structure in a private company creates a doorway for the majority to act opportunistically. ${ }^{6}$ It does not mean that it is wrong for the majority to act so that after all, the main reason for investing in an Indonesian Company is to receive profits. However, the problem would be if the shareholder is too succumbed by his greed that he decides to exercise his rights to the Indonesian Company's detriment and the other shareholders' interest. ${ }^{7}$ If committed by the majority shareholders, this kind of behaviour is termed abuse of rights by majority shareholders or based on its French roots abus de majorité. ${ }^{8}$ In essence, it refers to the improper use of rights by the majority shareholders by exercising their rights for purposes or in a manner disapproved by law, which resulted in losses incurred by the company and the minority shareholders. ${ }^{9}$

Such behaviour or concept is also recognized in other jurisdictions, albeit with different names. For example, in common law countries like the UK, the term is known as unfair

\footnotetext{
6 Paul L. Davies \& Sarah Worthington, Gower's Principles of Modern Company Law, 10th edn (London: Sweet \& Maxwell, 2016).

Paul L. Davies \& Sarah Worthington.

8 J. P.Legros, 'La Nullité Des Décisions de Sociétis', Revue Des Sociétés, 1991, 32-40.

9 S.Sangal.
} 
prejudice. ${ }^{10}$ In individual states in the US, it is known as oppression. ${ }^{11}$ In civil law countries, like Germany and the Netherlands, the concept is known respectively as a violation of the majority's duty of loyalty (mitgliedschaftliche treuepflicht) and violation of the principle of reasonableness and fairness. ${ }^{12}$ In the German context, the concept arises due to the duty of loyalty (treuepflicht) that is only found in a concentrated shareholding system or private companies where a group has a significant influence in directing the direction of the company. ${ }^{13}$ In comparison, although the term is not explicitly stated in the Dutch legal context, such concept can be drawn-out from the provision in the Dutch Civil Code, which obliges shareholders to behave towards one another reasonably and fairly (redelijkeid en billijkheid). ${ }^{14}$

The concept of abuse of rights ${ }^{15}$ is not expressly acknowledged in the Indonesian Company Law. However, a thorough observation of the Indonesian Company Law would show that such a concept is adopted, though implicitly. Perhaps, the most visible one can be seen through Article 3 of the Indonesian Company Law's stipulation, which stipulates that shareholders can be held personally liable for losses incurred by the Indonesian Company through the exploitation of the Indonesian Company assets in bad faith or through an unlawful act. The inscription of such conducts suggests that the Indonesian Company Law does recognize the concept of abuse of right by majority shareholders in which depicts the exercise of rights for purposes or in a manner disapproved by law. ${ }^{16}$

\section{Forms of Abuse of Rights by Majority Shareholders}

In 2017, the World Bank's research positioned Indonesia as the $40^{\text {th }}$ country that provides strong legal protection towards minority shareholders. ${ }^{17}$ Being positioned in such a place indicates how the practice of abuse of rights by majority shareholders is still pervasive. There are at least 4 (four) most common forms of abuse of rights.

\section{Withholding Dividends}

Abuse of rights by the majority can be committed in any forms. For example, in most private companies, the majority of shareholders would abuse their rights by depriving the minority shareholders' rights to receive dividends, even-though the Indonesian Company's net profit is sufficient. ${ }^{18}$ Since majority shareholders can control the GMS resolution to declare dividends(Law No. 40 of 2007, Article 71(2)), the minority shareholders may not receive any dividend at all. They may ultimately sell their shares at a price relatively below the actual value.

10 Reineer Kraakman.

11 S.Sangal.

12 Paul L. Davies \& Sarah Worthington.

13 Et.al Gregor Bachmann, Regulating the Closed Corporation (Berlin: De Gruyter, 2014).

14 Et.al J. Van Bekkum, 'Corporate Governance in the Netherlands', Electronic Journal of Comparative Law, 14.3 (2010), 1-35.

15 Nurhidayatuloh and others, 'Does Limitation Rule in International and Regional Human Rights Law Instruments Restrict Its Implementation?', International Journal of Recent Technology and Engineering, 8.2 Special Issue 9 (2019) <https://doi.org/10.35940/ijrte.B1125.0982S919>.

16 Fleischer

17 World Bank, 'Protecting Minority Investors', 2020.

18 Reineer Kraakman. 


\section{Dilution of Shares}

Besides, the majority of shareholders would abuse their GMS rights by diluting the minority shareholder's share through an issuance of new shares, capital reduction, mergers or acquisitions. ${ }^{19}$ All of these conduct can be committed by the majority shareholder through the GMS by having the GMS rendering a resolution in a manner that is in contravention to the law or in substance against the law. ${ }^{20}$ For example, the issuance of new shares without offering it to the minority shareholders due to the majority shareholders' inclination to dominate the shareholding structure can be deemed as an abuse of rights for the manner in issuing the new share is in contravention with the provision which states that every new share issued must be offered first to all existing shareholders(Law No. 40 of 2007, Article 43(1)).

The case of Siti Hutami Endang Adiningsih v. PT TH Indoplantation and PT Indopalms SDN BHD et al. is a perfect example of how majority shareholders' conduct can dilute the minority's share. ${ }^{21}$ The Plaintiff, Siti Hutami Hutami Endang Adiningsih, claimed that her share in PT TH Indoplantation had been reduced from ten per cent to five per cent due to the majority shareholder's, PT Indopalms SDN BHD, decision to convene an extraordinary GMS without the presence of the Plaintiff. The purpose of the extraordinary GMS was to discuss Defendant I plan to conduct an acquisition. However, the GMS was convened without the presence of the Plaintiff even though the Company's AoA stipulates that all shareholders with voting rights which includes the Plaintiff - are required. The Plaintiff further added that despite such provision, PT Indopalms SDN BHD kept pushing the GMS to be carried to approve the acquisition plan. In response to the claim brought by the Plaintiff, the District Court of South Jakarta decided that PT Indopalms SDN BHD should be held personally liable for the losses incurred by the Plaintiff and that the extraordinary GMS decision in question shall be deemed null and void.

\section{Misuse of Company's Assets for Personal Benefit}

Another common form of abuse of rights carried out by the majority shareholders involves the misuse of the company's assets for the majority shareholders' personal benefit. ${ }^{22}$ If left unresolved, the conduct may result in the dissipation of the company's assets that may reduce the value of the company and the diminishing of minority shareholders' interests.

The Indonesian Company Law stipulates that the diversion of more than fifty per cent of the company's assets has to be approved by the GMS or if without any GMS approval, has to be carried out in good faith ((Law No. 40 of 2007, Article 102 paragraph (1) and (4)). However, there are cases in which the company's assets are diverted to the detriment of the Indonesian Company's and the minority shareholder's interests. For example, in Gurays Assegaf v.

\footnotetext{
19 Reineer Kraakman.

20 Fleischer.

21 'District Court of South Jakarta, Decision No. 354/Pdt.G/2011/PN.Jkt.Sel.'

22 Reineer Kraakman.
} 
Muhammad Husen and Ghalib Muhammad 04/Pdt.G/2009/PN.Tgl, ${ }^{23}$ the Plaintiff, GurraysAssegaf, the minority shareholder of PT Gapura Pinus Nusantara, claimed that the Defendants, Muhammad Husen and Ghalib Muhammad, had quietly diverted the company's assets for their benefit.

Other jurisdictions also face the same issue. It can be seen in the case of Kieffer v. Budd presided in the New Jersey Superior Court. ${ }^{24}$ In the said case, the Plaintiff, Kieffer, a minority shareholder of a family-owned company, claimed that the Defendant, Budd, who was the majority shareholder, had diverted the company's assets to finance his son's business and to cover his family's personal expenses without Kieffer's knowledge. Kieffer argued that Budd's conduct had depleted the company's assets and adversely affect the company's ability to fulfil Kieffer's right in the company. ${ }^{25}$

\section{Dominating Corporate Boards}

It is also worth noting that the appointment of Direksi and Dewan Komisaris plays a massive part in enticing majority shareholders to abuse their rights. Perhaps, the primary factor for this is the absence of provision segregating the ownership, management, and supervisory positions in private companies. Without such limitation, majority shareholders would likely appoint themselves or their relatives to hold a managerial or a supervisory position within the Indonesian Company. ${ }^{26}$ Such an appointment could send a threatening message to the minority shareholders since it will give a more comprehensive opportunity for the majority shareholders to abuse their rights. ${ }^{27}$

One issue connected to the majority shareholders' domination in the corporate boards is the corporate guarantee. The corporate guarantee is basically an agreement in which an Indonesian Company, as the guarantor, sets a particular portion of its assets as a pledge to fulfil the payment of a debtor's debt. ${ }^{28}$ In many schemes, it is commonly found that a member of Direksi would put the company's asset as a guarantee for the majority shareholder's debt. ${ }^{29}$ This situation could happen under either two circumstances. Either because the debtor is a shareholder who has a close relationship with the member of Direksi or is the member of Direksi, or because the shareholder as the debtor holds the majority of shares in the Indonesian Company thus enabling him to dominate the votes in the GMS. Suppose the debtor fails to pay

23 'Gurays Assegaf v. Muhammad Husen and Ghalib Muhammad 04/Pdt.G/2009/PN.Tgl (District Court of Tegal,2009)'.

24 Court Listener, 'Michael D. Kieffer, Etc. Vs Charles A. Budd (C-0006-12, Gloucester County and Statewide)', 2017.

25 Michael P. Connolly, 'Watch Out For Minority Shareholder Oppression Claims After Admitting Non-Family Shareholders To The Family-Owned Business', Murtha Cullina Attorneys at Law, 2017.

26 Et.al Geoff Martin, 'Conflict Between Controlling Family Owners and Minority Shareholders: Much Ado About Nothing?', Entrepreneurship Theory \& Practice, 2016, 1-40.

27 Sandra K. Miller, 'Minority Shareholder Oppression in the Private Company in the European Community: A Comparative Analysis of the German, United Kingdom, and French Close Corporation Problem', Cornell International Law Journal, 30 (1997), 381-427.

28 Sri Soedewi Masjhoen Sofwa, Hukum Jaminan Di Indonesia: Pokok-Pokok Hukum Jaminan Dan Jaminan Perorangan (Security Rights under Indonesian Law: The Basics of Law on Security Rights and Personal Security) (Yogyakarta: Liberty, 1980).

29 Bo Gong, Understanding Institutional Shareholder Activism: A Comparative Study of the UK and China (London: Routledge, 2014). 
the debt. In that case, the minority shareholder of the Indonesian Company ${ }^{30}$ will suffer from a considerable loss within the Indonesian Company because his investment in the Indonesian Company will be taken away.

\section{Forms of Protection Against Abuse of Rights \\ Legal Action}

Share entails various rights that can be exercised by its holder. If one of the rights is infringed, then the shareholder concerned can file a lawsuit against those who prevent them from exercising these rights. ${ }^{31}$ That being said, minority shareholders can file a lawsuit against the Indonesian Company, the members of Direksiand Dewan Komisaris or even the majority shareholders for any decisions or actions that have created losses to the minority shareholders (Law No. 40 of 2007, Article 61 (1)). On the whole, the lawsuit contains the shareholder's plea to cease the performance of the harmful decision rendered on behalf of the Indonesian Company (Law No. 40 of 2007, Article 61 (1)). Thus, minority shareholders may ask the court to nullify a GMS decision that is rendered in a manner disapproved by law or in contravention to their rights as a shareholder.

\section{Appraisal Right}

If a shareholder disagrees with an Indonesian Company's decision, the shareholder can demand their shares to be purchased at a fair price (Law No 40 of 2007, Article 55 (1)). This kind of right is what is generally known as an appraisal right.

Even though the appraisal right is considered the most sought after measure for minority shareholders, one issue remains unresolved: how does one assess the fairness of the share's price. ${ }^{32}$ When determining the share's price, an evaluation of the Indonesian Company's past, present and future performance must be considered. ${ }^{33}$ The concern here is whether the share's price will affect the longevity and the value of the Indonesian Company. ${ }^{34}$ In the end, the minority shareholder's share may be undervalued, especially when the Indonesian Company does not have enough money to repurchase it. ${ }^{35}$

Furthermore, the repurchase of share by an Indonesian Company can only be conducted if it does not cause the net asset becoming less than the total of subscribed capital and the mandatory reserves combined. The repurchase is required not to exceed ten per cent of Indonesian Company's subscribed capital (Law No. 40 of 2007, Article 37 (1)). However, if the Indonesian Company does not have sufficient funds to repurchase the share, then the remaining

30 Putu Samawati, 'Legal Reasons Underlying Demonopolization by State-Owned Enterprises in Indonesia', Sriwijaya Law Review, 3.2 (2019), 124-36 <https://doi.org/10.28946/slrev.Vol3.Iss2.126.pp124-136>.

31 Binoto Nadapdap, Hukum Perseroan Terbatas: Berdasarkan Undang-Undang No. 40 Tahun 2007 (Limited Liability Company Law: In Accordance with Law No. 40 Year 2007) (Jakarta: Jala Permata Aksara, 2016).

32 'District Court of South Jakarta, Decision No. 354/Pdt.G/2011/PN.Jkt.Sel.'

33 Mishardi Wilamarta, Hak Pemegang Saham Minoritas Dalam Rangka Good Corporate Governance (Minority Shareholders' Rights in Good Corporate Governance) (Jakarta: Fakultas Hukum Universitas Indonesia, 2012).

34 'District Court of South Jakarta, Decision No. 354/Pdt.G/2011/PN.Jkt.Sel.'

35 F. Hodge O'Neal and Robert B. Thompson, 'O'Neal's Close Corporations', Law and Practice, 2.1 (1992), 1011. 
share will be offered to a third party (Law No. 40 of 2007, Article 61(2)). Unfortunately, third parties are sometimes unmotivated to pay a large sum of money to purchase a minority share. ${ }^{36}$

\section{Pre-emptive Right}

The Indonesian Company Law provides that the AoA of an Indonesian Company may stipulate that a newly issued share shall be offered first to the existing shareholders (Law No. 40 of 2007, Article 57 (1) \& Article 58 (1)). Furthermore, a pre-emptive right can also be exercised by the minority shareholders when an Indonesian Company decides to increase its capital by issuing a new share (Law No. 40 of 2007, Article 43). Shareholders are given 14 (fourteen) days, since the day of the offer, to carry out their pre-emptive right (Law No. 40 of 2007, Article 43 (4)). If within the 14 (fourteen) days period no purchase is made then the Indonesian company will offer the newly issued share to a third party (Law No. 40 of 2007, Article 43 (4)).

\section{Inquiry Right}

Shareholders have the right to submit a petition to the court to conduct an inspection over the Indonesian Company under the presumption that the Indonesian Company or the members of the organs thereof have committed an act that harms the interest of the Indonesian Company or the shareholders (Law No. 40 of 2007, Article 138 (1) \& (2)). Such right performed by the shareholders concerned is what is prominently known as the inquiry right or enqueterechtrecht. ${ }^{37}$

The primary purpose of inspecting an Indonesian Company is to obtain data or information regarding an Indonesian Company (Law No. 40 of 2007, Article 138 (1)). The data or information requested may serve as evidence for the petitioner to confirm whether the Indonesian Company or members of the organs thereof have committed an unlawful act that creates losses to either the Indonesian Company itself, the shareholders or a third party. ${ }^{38}$

The Indonesian Company Law prescribes that only 1 (one) or more shareholders who represent at least one-tenth of the total number of shares with voting rights can request the court to allow an inspection towards the Indonesian Company (Law No. 40 of 2007, Article 138(3)). That being said, it is impossible for minority shareholders whose total number of shares does not make up this condition by submitting an inspection petition.

Petition to inspect an Indonesian Company is only available to the shareholder after the Indonesian Company has refused the shareholder's direct request to obtain the data and information needed. ${ }^{39}$ In other words, a shareholder's petition to inspect an Indonesian Company will be instantly rejected if it is revealed that the shareholder has not asked the Indonesian Company to disclose any data or information needed.

\footnotetext{
36 'District Court of South Jakarta, Decision No. 354/Pdt.G/2011/PN.Jkt.Sel.'

37 Alessio Pacces, Rethinking Corporate Governance: The Law and Economics of Control Powers (London: Routledge, 2012).

38 S.Sangal.

39 Pacces.
} 


\section{Personal Liability of Shareholders}

Essentially, shareholders are not personally liable for any activities conducted on behalf of the Indonesian Company (Law No. 40 of 2007, Article 3(1)). However, this limited liability nature can be set aside under certain circumstances.

1. Incorporation requirements have not been fulfilled

The limited liability nature of an Indonesian Company is borne once the Indonesian Company obtains its legal status. In order to obtain its legal status, some requirements must be fulfilled. Furthermore, an Indonesian Company can only be regarded as one once it obtains its legal status from the Minister of Law and Human Rights (Law No. 40 of 2007, Article 7 paragraph (4)). Therefore, if there has been no decree issued by the Minister to ratify the Indonesian Company's legal status, the shareholders will be held personally liable for any legal actions performed on behalf of the Indonesian Company (Law No. 40 of 2007, Article 3 (2)).

2. Shareholders have committed an abuse of rights

In civil law countries such as France, Germany, ${ }^{40}$ and the Netherlands concept of abuse of rights is utilized to hold majority shareholders liable for voting against the company and the minority shareholders' interests in order to advance their personal interest. ${ }^{41}$ In resemblance, common law countries like the UK gives an option to hold majority shareholders personally liable for any wrongdoings committed against the minority's interest under the unfair prejudice claim. Lawsuits filed based on abuse of rights by majority shareholders may result in the nullification of a GMS decision and/or payment of damages. $^{42}$

Additionally, the Indonesian Company Law provides that shareholders can be held personally liable when they have created losses to the Indonesian Company by way of either exploiting the Indonesian Company in bad faith or by being involved in an unlawful act committed by the Indonesian Company or by unlawfully using the Indonesian Company's assets for their personal interest (Law No. 40 of 2007, Article 3(1) \& (2)).

\section{Case Study in Indonesian Court}

The following cases represent the court's opinion when deciding disputes between shareholders in a family-owned company. The first case elaborates the dispute between Conal Kanginan and Christian Kanginan v. Fadjar Kanginan, Maria Elena Kanginan, and Meiliana Halim. The second case discusses the dispute between Jhon Kumala v. PT. Karya Lestari Makmur and Priyana Nuryadi v. Jhon Kumala. In both cases, the court opined that the majority of shareholders had committed an unlawful act by way of contravening or depriving the minority shareholders right.

40 Martin Gelter Pierre-Henri Conac, L. Enriques, 'Constraining Dominant Shareholders' Self-Dealing: The Legal Framework in France, Germany, and Italy', European Company and Financial Law Review, 4 (2007), 491-528.

${ }^{41}$ Gong.

42 Luca Enriques, 'Enforcing Self-Dealing Constraints on Dominant Shareholders in Europe', 2020. 


\section{Conal Kanginan and Christian Kanginan v. Fadjar Kanginan et.al.737/Pdt.G/2014 ${ }^{43}$}

The first case concerns the dispute between Conal Kanginan and Christian Kanginan v. Fadjar Kanginan, Maria Elena Kanginan, and Meiliana Halim. The minority shareholders of PT. Giunco Kota Mas ("PT GKM"), Conal Kanginan and Christian Kanginan ("the Kanginan brothers") filed a lawsuit against Fadjar Kanginan ("Defendant I") and Maria Elena Kanginan ("Defendant II") who together constitute as the majority shareholders of PT GKM. The Kanginan brothers argued that the majority of shareholders have intentionally used their absence during PT GKM's GMS to purchase all of the newly issued share, thus creating a dilution of share. Due to this event, The Kanginan brothers argued that it is plausible for them to file a lawsuit against the defendants based on Article 61 of the Indonesian Company Law.

Concerning this case, the court argued that the Kanginan brothers have a pre-emptive right conferred by the AoA of PT GKM to purchase the newly issued share. Thus, the defendants' action to not allow the defendants not to purchase or not receive any offers regarding the newly issued share did contravene the Kanginanbrothers' right as shareholders. Furthermore, their action to instantly purchase the share by setting aside the brothers' pre-emptive right, has created losses in which the brothers' ownership over the Indonesian Company has now been reduced.

However, there is one crucial point that shall be addressed in response to this court decision. The court and the Kanginan brothers seem to have conjured up a false interpretation of Article 61 of the Indonesian Company Law. The court should have rejected the lawsuit, since, the Kanginan brothers used Article 61 of the Indonesian Company Law instead of Article 3 paragraph (2) of the Indonesian Company Law as their legal basis to hold the defendants personally liable. It is because Article 61 requires the brothers as shareholders to file the lawsuit against the Indonesian Company where he/she is a shareholder of the brothers filed the lawsuit against the majority shareholders. That being said, it is more befitting for the brothers to use Article 3 paragraph (2) letter $\mathrm{c}$ of the Indonesian Company Law as their legal basis. It is because this provision is meant to hold a shareholder personally liable for any unlawful act committed by the Indonesian Company.

\section{Jhon Kumala v. PT. Karya Lestari Makmur and Priyana Nuryadi $2108 \mathrm{~K} / \mathrm{Pdt} / 2015^{44}$}

The second case concerns the dispute between Jhon Kumala v. PT. Karya Lestari Makmur and Priyana Nuryadi. Jhon Kumala ("Kumala"), the Plaintiff, in this case, is the holder of the twenty per cent of the total shares with voting rights in PT Karya Lestari Makmur. Kumala has filed a lawsuit against PT Karya Lestari Makmur ("Defendant I") whose majority shareholders comprise of Priyana Nuryadi ("Defendant II") and her siblings.

Kumala claimed that the defendants owed Kumala a total of US\$1,122,500 (one million and one hundred and twenty-two thousand and five hundred) for his unfulfilled rights to receive dividends, salary as an employee and bonus fee as a managing director. Kumala adds that Defendant II as both a majority shareholder and a member of Direksi in the Indonesian Company has withheld Kumala's right to receive dividends even-though Kumala has asked for

\footnotetext{
43 'Conal Kanginan and Christian Kanginan v. Fadjar Kanginan et.Al. 737/Pdt.G/2014/PN.Sby (District Court of Surabaya, 2015)'.

44 'Jhon Kumala v. PT Karya Lestari Makmur And Priyana Nuryadi 2108 K/Pdt/2015 (Supreme Court of Indonesia, 2015)'.
} 
the completion of his right to be delivered. In the lawsuit, Kumala has submitted a plea to deem the defendants to have committed an unlawful act. Kumala also pled with the court to order the defendants to pay him a total of 1,122,500 (one million and one hundred and twenty-two thousand and five hundred) for the unfulfilled rights that he had yet received.

The court agreed that the defendants should have paid Kumala his dividends on the basis that every shareholder has the right to receive payments from dividends. This reasoning is undoubtedly coherent with Article 52 paragraph (1) of the Indonesian Company Law, which has assertively stipulated that every shareholder's right to receive payments from dividends. The court stipulated that Kumala's right to receive his dividend was further reaffirmed through the existence of two agreements in which show the amount of dividend that Kumala shall receive as a shareholder.

However, the court did not order the Defendant to pay in the amount requested by Kumala in his lawsuit. During the hearing, it is proven that the amount requested in the lawsuit does not mirror the evidence brought to the court regarding the amount of payment that the defendants still owed to Kumala. Other than that, the court stated that Kumala has failed to prove any unfulfilled payment other than the defendants' dividend. In the end, the court ordered the defendants to pay Kumala for his right as a shareholder in the amount of USD \$ 66,801 (sixtysix thousand and eight hundred and one).

One takeaway that we can draw from the analysis of these court cases is that given the one share one vote principle majority shareholders has an immense control in directing the Indonesian Company's decision. It is because their substantial amount of share leads them into having superior voting power. ${ }^{45}$ On the other hand, minority shareholders who own less than what the majority has would certainly fail to compete in exerting control over the company.

\section{CONCLUSION}

Majority shareholders in a family-owned company are likely to rely on certain forms of abuse of rights to pursue their interests. Such forms include the majority shareholders' effort to withhold dividends, misuse the company's asset, dilute the minority's interest, and dominate the corporate boards. To prevent this conduct, indeed, the Indonesian Company Law provides various legal measures for minority shareholders to protect their interest against the majority shareholders' actions. Minority shareholders can invoke their personal right, appraisal right, inquiry right, and pre-emptive right to safeguard their interest against the majority shareholders' abuse of rights. However, despite all the legal measures available, several weaknesses are found when affirming the minority shareholders' and the Indonesian Company's interest. These weaknesses include the possibility of a minority's share being undervalued when implementing their appraisal right and the inability for minority shareholders to file a legal suit on behalf of the Indonesian Company against the majority shareholders.

The examination of two court decisions suggests that the court tends to render a decision in favour of the minority shareholders' interest. However, the court did not always pass the same

45 Gerard V.Mantese and Ian M. Williamson, 'Litigation Between Shareholders in Closely-Held Corporations: Protecting Minority Shareholders from Abuse at the Hands of Majority Owners', Wayne Law Journal of Business, 2017, 1-27. 
verdict as the minority shareholders pled. It can be seen in the case of Jhon Kumala v. PT. Karya Lestari Makmur and Priyana Nuryadi, where the court only ordered the defendants to pay Kumala for his right as a shareholder in the amount less than what Kumalapleaded. As a side note, in its examination, the court has sometimes mistreated some of the legal measures available for minority shareholders. As seen in the case of Conal Kanginan and Christian Kanginanv, Fadjar Kanginan et al., where the court approved the Kanginan brothers to use the wrong legal basis to hold the defendants personally liable.

Abuse of rights by majority shareholders is still a contingent issue in family-owned companies in Indonesia. Therefore, it is best to create more stringent rules to prevent this behaviour. Moreover, provisions limiting the influence of majority shareholders in corporate boards would seem crucial at this point, for the interest of both minority shareholders and Indonesian Companies is mostly set aside and not represented in family-owned companies.

\section{REFERENCES}

Bahls, Steven C., 'Resolving Shareholder Dissension: Selection of the Appropriate Equitable Remedy', Journal of Corporation Law, 15 (1990), 285-89

Bank, World, 'Protecting Minority Investors', 2020

'Conal Kanginan and Christian Kanginan v. Fadjar Kanginan et.Al. 737/Pdt.G/2014/PN.Sby (District Court of Surabaya, 2015)'

Connolly, Michael P., 'Watch Out For Minority Shareholder Oppression Claims After Admitting Non-Family Shareholders To The Family-Owned Business', Murtha Cullina Attorneys at Law, 2017

'District Court of South Jakarta, Decision No. 354/Pdt.G/2011/PN.Jkt.Sel.'

Enriques, Luca, 'Enforcing Self-Dealing Constraints on Dominant Shareholders in Europe', 2020

Fleischer, Holger, 'Comparative Corporation Governance in Closely Held Corporations', in The Oxford Handbook of Corporate Law and Governance, ed. by J. N Gordon and W Ringeeds, The Oxford (Oxford: Oxford University Press, 2018)

Geoff Martin, Et.al, 'Conflict Between Controlling Family Owners and Minority Shareholders: Much Ado About Nothing?', Entrepreneurship Theory \& Practic, 2016, 1-40

Gong, Bo, Understanding Institutional Shareholder Activism: A Comparative Study of the UK and China (London: Routledge, 2014)

Gregor Bachmann, Et.al, Regulating the Closed Corporation (Berlin: De Gruyter, 2014)

'Gurays Assegaf v. Muhammad Husen and Ghalib Muhammad 04/Pdt.G/2009/PN.Tg1 (District Court of Tegal, 2009)'

J. Van Bekkum, Et.al, 'Corporate Governance in the Netherlands', Electronic Journal of Comparative Law, 14.3 (2010), 1-35

'Jhon Kumala v. PT Karya Lestari Makmur And Priyana Nuryadi 2108 K/Pdt/2015 (Supreme Court of Indonesia, 2015)'

Listener, Court, 'Michael D. Kieffer, Etc. vs. Charles A. Budd (C-0006-12, Gloucester County 
and Statewide)', 2017

Miller, Sandra K., 'Minority Shareholder Oppression in the Private Company in the European Community: A Comparative Analysis of the German, United Kingdom, and French Close Corporation Problem', Cornell International Law Journal, 30 (1997), 381-427

Moll, Douglas K., 'Shareholder Oppression \& Dividend Policy in the Close Corporation', Washington \& Lee Law Review, 60.3 (2003), 841-924

Nadapdap, Binoto, Hukum Perseroan Terbatas: Berdasarkan Undang-Undang No. 40 Tahun 2007 (Limited Liability Company Law: In Accordance with Law No. 40 Year 2007) (Jakarta: Jala Permata Aksara, 2016)

Nurhidayatuloh, Febrian, Y. Annalisa, A. Idris, R.M. Ikhsan, S. Helena Primadianti, and others, 'Does Limitation Rule in International and Regional Human Rights Law Instruments Restrict Its Implementation?', International Journal of Recent Technology and Engineering, 8.2 Special Issue 9 (2019) 〈https://doi.org/10.35940/ijrte.B1125.0982S919>

P.Legros, J., 'La Nullité Des Décisions de Sociétis', Revue Des Sociétés, 1991, 32-40

Pacces, Alessio, Rethinking Corporate Governance: The Law and Economics of Control Powers (London: Routledge, 2012)

Paul L. Davies \& Sarah Worthington, Gower's Principles of Modern Company Law, 10th edn (London: Sweet \& Maxwell, 2016)

Pierre-Henri Conac, L. Enriques, Martin Gelter, 'Constraining Dominant Shareholders' SelfDealing: The Legal Framework in France, Germany, and Italy', European Company and Financial Law Review, 4 (2007), 491-528

Reineer Kraakman, Et.al, The Anatomy of Corporate Law: A Comparative and Functional Approach (3) (Oxford: University Press, 2017)

S.Sangal, P., 'Abuse of Authority by a Majority of Shareholders in a Company', Journal of the Indian Law Institute, 6.4 (1964), 380-409

Samawati, Putu, 'Legal Reasons Underlying Demonopolization by State-Owned Enterprises in Indonesia', Sriwijaya Law Review, $3.2 \quad$ (2019), 124-36 <https://doi.org/10.28946/slrev.Vol3.Iss2.126.pp124-136>

Sofwa, Sri Soedewi Masjhoen, Hukum Jaminan Di Indonesia: Pokok-Pokok Hukum Jaminan Dan Jaminan Perorangan (Security Rights under Indonesian Law: The Basics of Law on Security Rights and Personal Security) (Yogyakarta: Liberty, 1980)

Thompson, F. Hodge O'Neal and Robert B., 'O'Neal's Close Corporations', Law and Practice, 2.1 (1992), 10-11

Wilamarta, Mishardi, Hak Pemegang Saham Minoritas Dalam Rangka Good Corporate Governance (Minority Shareholders' Rights in Good Corporate Governance) (Jakarta: Fakultas Hukum Universitas Indonesia, 2012)

Williamson, Gerard V.Mantese and Ian M., 'Litigation Between Shareholders in Closely-Held Corporations: Protecting Minority Shareholders from Abuse at the Hands of Majority Owners', Wayne Law Journal of Business, 2017, 1-27 